Perspective .

\title{
The Festschrift: A Festival of Writings
}

\section{Gilbert I. Martin, MD}

The term "festschrift," from German, is a compound word with two separate meanings: the first, "fest," means a "festival" or "feast"; the second, "schrift," means simply "writings." In the past, a festschrift represented a volume of articles or essays contributed by many authors in honor of a colleague, usually on the occasion of retirement.

We dedicate this issue to L. Joseph Butterfield as a Festschrift. We review his qualities as scientist, innovator, physician, teacher, author, ambassador, administrator, and musician. It is fitting that this first issue of the Journal of Perinatology, as the Official Journal of the Section of Perinatal Pediatrics of the American Academy of Pediatrics, is dedicated to Dr. Butterfield. As the founder of "Newborn Country, USA" he has contributed greatly to improving health care for mothers and babies. The Festschrift commentaries depict Dr. Butterfield in many of these roles. The articles written by his colleagues continue to echo the innovative style that has made his professional life so rewarding.

Note that one of the commentaries is in the form of a song entitled: The Butterfield Blues: Newborn Country, USA. If you are interested in receiving a tape of this song, call the editorial office of the Journal.

Citrus Valley Medical Center, West Covina, CA.

Address correspondence and reprint requests to Gilbert I. Martin, MD, Citrus Valley Medical Center, 1115 S. Sunset Avenue, West Covina, CA 91793.
This "Festival of Writings" touches on perinatal-neonatal history and should be interesting to all readers of the Journal. Dr. Butterfield continues to work actively to promote many causes. Most importantly, he remains accessible to all who ask for his opinion or advice.

The editors of the Journal of Perinatology are honored to be able to dedicate this Festschrift to L. Joseph Butterfield.



1998: L. Joseph Butterfield, MD, at the "Hot Topics" meeting in Washington, DC beside a poster of the late Dr. Virginia Apgar. The poster features a classic photograph by Elizabeth Wilcox, former photographer at the College of P\&S at Columbia University. The $13^{\prime \prime} \times 10^{\prime \prime}$ poster is available for a donation of $\$ 20$ or more. The proceeds go to support the Apgar Memorial String Quartet, which uses the four stringed instruments that Dr. Apgar crafted with the tutelage of Carleen Maley Hutchins from Montclair, NJ. The instruments were purchased by the AAP Perinatal Section and donated to the College of Physicians and Surgeons as The Apgar Memorial String Quartet in her memory. 